\title{
REN Gene
}

National Cancer Institute

\section{Source}

National Cancer Institute. REN Gene. NCI Thesaurus. Code C113589.

This gene plays a role in angiotensin metabolism. 